Short communication

UDC $94(3)$

DOI $10.18413 / 2312-3044-2020-7-2-166-168$

\title{
Sources on the Late Antiquity
}

\author{
V. V. Serov \\ Altai Institute of Economics \\ Lenina pr. 106e, Barnaul, 656011, Russia \\ E-mail: wseroff@yandex.ru
}

Copyright: (C) 2020 Serov, V. V. This is an open-access publication distributed under the terms of the Creative Commons Attribution License, which permits unrestricted use, distribution, and reproduction in any medium, provided the original authors and source, the Tractus Aevorum journal, are credited.

The questions posed by the need for a full-scale definition of the "late antiquity", though totally artificial, are crucial for the study of the history of mankind from the standpoint of a civilizational approach and seem not to have been completely resolved to date. The the prospects for their solution will remain vague until the development of generally accepted defining criteria for the phenomenon of late antique civilization. Obviously, this will not happen soon, and the participants in the discussion about the essence of late antiquity, its chronological and geographical boundaries, will remain divided into groups of beliefs for a long time to come.

However, the differences in modern ideas about the essence of late antiquity (among those researchers who recognize the legitimacy of the very existence of this concept) are not so significant and come down, in general, to different assessments of the degree and quality of the civilizational fracture and, accordingly, the time of its onset and duration. Without delving into the historiography of this problem and the analysis of points of view, it can be noted that the leitmotif of most of the studies is the recognition of the significant changes in the consciousness of people that occurred in the Late Antique era (no matter how long it took).

And if one agrees with the acceptable thesis that such mental changes are the main content of the late Antique period, then disagreements over its chronology and geography easily transform from general to local (regional) and narrow. In the historiography of late antiquity, this, in fact, is the case. The study of this phenomenon departed from the discussion of the concept itself as an unpromising topic and focused on its main characteristics, first of all, on types and trends of personality transformation.

ISSN 2312-3044 | http://belsu-tractus-aevorum.ru 
A vivid example is the written sources that allow us to accurately capture the civilization transition. We are talking about groups of narrative documents that, by the evolution of the form and content of the text, demonstrate changes in the ideology and mentality of certain social strata and, to a certain extent, of the entire ancient society.

There are few source groups that unite a representative number of different monuments of thought. However, they must be supplemented by a number of sources that are not extensive or numerous but characterizing the era by the very fact of their appearance (and sometimes disappearance). On the whole, the clear markers of late-antique mental transformation are: historical works; collections of laws and regulations; the Christian literary heritage, which characterizes the advent of the new era of sui sponte and should be treated separately.

The former and latter of these are full-fledged groups of sources studied for compliance with the thesis of the epoch-making change in the consciousness of ancient man in great detail during the time that has passed since the publication of the fundamental work by Peter R. L. Brown ${ }^{1}$. On the contrary, the imperial legislation for an unusually long period for Roman studies $\left(3^{\text {rd }}-4^{\text {th }}\right.$ centuries) did not gain sufficient attention. The reason for this is the formal difference between legislation as a type of historical sources and literary records, although the laws were also written by people of their era, and you can also find traces of changes in the consciousness of representatives of the educated people that interest researchers of the world of late antiquity.

What makes it possible to classify legislative sources of late antiquity as characteristics of the era? First of all, it is the opportunity to trace longterm formal changes, the changing amount of text and the subsequent political desire to structure legislation. It seems that the first experience of streamlining an overwhelming mass of laws and norms is associated with the emergence of the so-called "eternal edict", as well as of the "institutions" of Gaius and, in general, with the systematic activity of Roman lawyers of the $2^{\text {nd }}-$ early $3^{\text {rd }}$ centuries. They, of course, acted on their own initiative and on the basis of social necessity, but at the same time served the practical needs of the growing imperial power, which also acted as a kind of symbol of the transitional era. Very soon, the emperors subordinated jurisprudence to their interests, and already at the end of the $3^{\text {rd }}$ century the first real codes of laws appeared (codex Gregorianus and codex Hermogenianus). Their original texts have not been preserved, but there is no doubt that these were thematically grouped imperial orders interspersed with the maxims of famous lawyers of the past "golden age". In these first records of late antique lawmaking, both the direction of development of social thought and the essence of a brewing mental fracture clearly appear. Antique public consciousness, free and creatively uninhibited, gradually got used to coexist

\footnotetext{
${ }^{1}$ Brown P. The World of Late Antiquity: AD 150-750. N. Y., 1971.
} 
and in many respects obey the discipline of authoritarian power, which, however, has not yet completely separated itself from most of the foundations of the ancient world order, for example, from the concept of citizenship.

The concept of imperial power, which developed along with the principles of lawmaking, did not dissolve the "civilian" component at least until the late $6^{\text {th }}$ century (the absence of a later narrative does not allow us to trace the fate of the corresponding conceptual provisions). Thus, for example, emperors preserved this public institution in such a sanctum sanctorum of the state as the imperial treasury, with "public" becoming the analogue of "imperial". On this particular issue, the final turning point did not occur either in late antiquity or in the Middle Ages, and the ideology of imperial power was never "late antique" in history.

It is generally accepted that the codification carried out in 528-534 was the pinnacle of the development of legal thought in late antiquity. Formally, this fact is undeniable. However, legislative sources following the creation of the Justinian Code reveal a further development of legal consciousness, which continued to apply the developed paradigm of late antique imperial law to all new objects in the legal field.

For example, after 534, the economic activity of the Orthodox Church became the subject of legal reflection in the light of changing late antique law, which led, among other things, to the emergence of such a specific kind of codification as nomocanons (from the end of the $6^{\text {th }}$ century), which were actually a reaction of the church excessive caesar-centered legal unification and acted as an indicator of the completeness of a mental fracture in one of the segments of the Late Antique society. The latest post-Justinian "codifications" (Eclogue, Procheiron and the first editions of Basilika), although they were simplifications of the greatest codes of the past, reflected the ongoing multifaceted transformation of the later ancient society and state and their transformation into medieval ones. In this case, it should be recognized that late antiquity in the field of jurisprudence lasted until the $9^{\text {th }}$ century, and the notorious break in the legal aspect of public consciousness is stretched for almost eight centuries, which may explain the beginning of reception of Roman law in the early Middle Ages.

Thus, on the basis of legislative historical sources, it is necessary to state the unresolved problems of the universal definition of "late antiquity", as well as the prospective possibility of identifying this phenomenon as a result of a comprehensive analysis of all available historical material related to the mental activity of the "ancient" man throughout the first nine centuries after the birth of Christ. In addition, the material of the "Late Antique" legislation, collected in various collections and codes, pushes the boundaries of the era of late antiquity, which almost continuously flows into the Middle Ages.

Received March 17, 2020

Translated from Russian by Alexander M. Amatov

Published December 14, 2020 